gesprochen nach $5^{\text {h }}$ auftritt, wo die Sonne hinter den Bergen verschwindet. Was aber hat das starke Emporschnellen der Helligkeit um $5^{\mathrm{h}} 4^{\mathrm{m}}$ zu bedeuten, nach welchem dann die Abnahme von neuem einsetzt? Es ist bekannt, daß auf das Selen besonders das rote Licht wirkt "weshalb das Dämmerlicht, mit einem Selenauge betrachtet, viel zu stark erscheint * (A. N. 407 I). Darf man annehmen, daß hier I I Minuten vor dem wirklichen Sonnenuntergang die Tinten eines Abendrotes auf die Selenzelle gewirkt haben, das dem Menschen, der hinter dem Wolkenvorhang (und unter dem Laubdach eines Baumes) sein Auge nicht nach oben, sondern nur auf die Ableseskala gerichtet hatte, unsichtbar blieb?

Der weitere Abfall des Lichtes nach dem Sonnenuntergang um $5^{\mathrm{h}} 59^{\mathrm{m}}$ ist weniger steil, als der vor der Totalität. Nun betrachten wir die Figur 2.

In ihr ist die Widerstandskurve um die Totalität herum und daneben die des Sonnenuntergangs in größerem Maßstabe wiedergegeben, im zehnfachen der Abszissen und im doppelten der Ordinaten. An der sehr regelmäßigen Kurve der Totalität fällt der große Abstand des Punktes $22^{\mathrm{h}}{ }^{\mathrm{i}} 5^{\mathrm{m}} 5^{6^{\mathrm{s}}}$ mit nur 80 I $_{3} \mathrm{Ohm}$, von dem Io voraufgehenden mit $9637 \mathrm{Ohm}$ auf. Hier hat die Selenzelle den ersten Strahl des wiederkehrenden Sonnenlichtes empfangen und darauf mit einem Sprunge der Nadel nach oben reagiert; hier ist der dritte Kontakt. Da die Reaktionszeit oben $2 \mathrm{u} 29^{5}$ ermittelt ist, so folgt daraus für den Moment des dritten Kontaktes $22^{\mathrm{h}} \mathrm{r}^{\mathrm{m}} 27^{\mathrm{s}}$, wovon freilich bis zu 9 Sekunden abzuziehen sind, da nur alle zehn Sekunden eine Ablesung gemacht ist. Zieht man $5^{5}$, also die Hälfte des Intervalles $a b$, so käme man genau auf den Wert der Vorausberechnung. Auch der zweite Kontakt ist in der Kurve angedeutet, indem der steile Abstieg, der bis $22^{\mathrm{h}} 13^{\mathrm{m}} 57^{\mathrm{s}}$ erfolgte, dort einen Knick zu langsamerem Abfall zeigt: Dies entspricht dem, was erwartet werden muß. Neben der leuchtenden Sonnensichel kommt das Koronalicht nicht zur Geltung, sodaß der Verlauf der Helligkeitskurve kurz vor dem zweiten Kontakt so ist, als ob nach diesen absolute Dunkelheit eintreten würde. Kommt statt dessen mit dem zweiten Kontakt das Koronalicht zur Geltung, so ist also die Helligkeit größer, als nach dem bisherigen Verlaufe der Kurve zu erwarten ist, und die Kurve muß daher einen Knick nach rechts zeigen, wie sie dies tut. Der erste abweichende Kurvenpunkt um $22^{\mathrm{h}} \mathrm{I}^{\mathrm{m}} 7^{\mathrm{s}}$ liegt $\mathrm{I}^{\mathrm{m}} 5^{\mathrm{s}}$ vor dem mit der Selenzelle beobachteten dritten Kontakt, entsprechend der berechneten Dauer der Totalität von 112 Sekunden. Genau wie dies Wulf am a. O. findet, ist auch hier der Widerstand der Zelle am Ende der Totalität am größten.

In der Kurve der Dämmerung prägt sich der Moment des Untergangs der Sonne unter den astronomischen Horizont um $5^{\text {h }} 59^{\mathrm{m}}$ deutlich aus (gerade wie bei $W u l f$ ), indem nach her die Kurve steiler absinkt, obwohl die Sonne selbst schon eine Stunde früher hinter den Bergen im Westen verschwunden war. Der gleiche Widerstand der Zelle wie während der Totalität von $9640 \mathrm{Ohm}$ war erreicht um $6^{\mathrm{h}} 19^{\mathrm{m}} 22^{\mathrm{s}}$, also 20 Minuten nach dem astronomischen Sonnenuntergang. Bald darauf stürzt die Kurve fast senkrecht abwärts dem Dunkel der Nacht entgegen.

Da die Zahl der bisherigen Beobachtungen mit Selenzellen während totaler Sonnenfinsternisse nicht groß ist, hielt ich es für angemessen, das bescheidene Resultat der chilenischen Expedition nach Christina nicht zu unterdrücken, zumal es die Leistungsfähigkeit des Selens selbst unter den obwaltenden so ungünstigen Umständen zeigt.

Santiago de Chile, r 9 I 2 Dezember.

F. W. Ristenpart.

\title{
Beobachtung der Sonnenfinsternis 1912 Oktober 9 auf der Sternwarte Santiago de Chile.
}

\section{Von R. Prager.}

Die Finsternis, die hier eine Größe von 0.4 erreichte, vollzog sich teilweise hinter Wolken. Doch konnten die beiden Kontakte, wenn auch unter ungünstigen Bedingungen, beobachtet werden.

Am Repsoldschen Refraktor (2 $40 \mathrm{~mm}$ Objektivöffnung, 4.3 $\mathrm{m}$ Brennweite) war ein Projektionsschirm angebracht, um mehreren Beobachtern die Verfolgung des Phänomens zu ermöglichen. Beim Eintritt war der Rand stark wallend, das Sonnenbild wegen der dichten Wolken nur schwach zu sehen. Auch beim Austritt, als die Sonne schon ziemlich hoch stand, war das Bild sehr unruhig, doch sind hier die Beobachtungen sicherer.

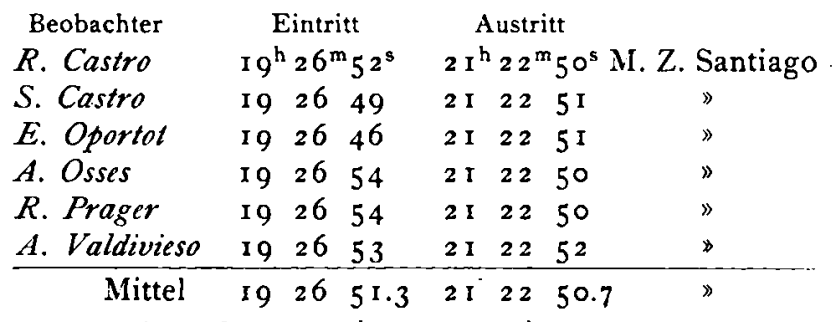

Dem entspricht Okt. Io $0^{\mathrm{h}} 9^{\mathrm{m}} 37^{\mathrm{s}} 62^{\mathrm{h}} 5^{\mathrm{m}} 37^{\text {so }}$ M. Z. Greenw.
Die vorausberechneten Momente waren:

\begin{tabular}{|c|c|c|}
\hline Eintritt & Austritt & \\
\hline $9^{m} 35^{s} \cdot$ & $2^{h} 5^{m} 39^{s} .6$ & \\
\hline $944 \cdot 3$ & 26 & \# \\
\hline 945. & 26 & 》 \\
\hline $\begin{array}{ll}9 & 47.8\end{array}$ & 26 & » \\
\hline
\end{tabular}

American Ephemeris

Connaissance des Temps

Berliner Jahrbuch

Nautical Almanac$$
\begin{array}{lllllll}
0 & 9 & 47.8 & 2 & 6 & 2.5
\end{array}
$$

Wie bei der Finsternis r 9 I 2 April I 7 zeigt sich auch hier, daß die in der American Ephemeris angewandten Newcombschen empirischen Korrektionen der Mond-Koordinaten und -Parallaxe den Beobachtungen am genauesten entsprechen.

Die Finsternis wurde, soweit das Wetter es gestattete, im ganzen Lande mit Interesse beobachtet. Von den der Sternwarte darüber zugegangenen Mitteilungen hat vielleicht die folgende Wahrnehmung, die ich einem Briefe von Herrn $F$. Ohde in Valdivia entnehme, allgemeineres Interesse:

»Zur Zeit der Finsternis war der Himmel bewölkt; bei dem ziemlich heftigen Westwind zerriß die Wolkendecke öfters, sodaß man die Sonne dann sehen konnte, meist jedoch noch durch einen mehr oder weniger dichten Wolken- 
schleier. Ich beobachtete durch farbige Glasscheiben, ich hatte eine grüne und eine rote Scheibe, welche ich übereinander legte. Gegen 9 Uhr konnte ich mit noch einigen Mitgliedern meiner Familie die ganze Mondscheibe erkennen, welche scheinbar unten an der Sonne hing, jedoch nur für einige Sekunden, nachher war sie nicht mehr sichtbar. Der Hinmelsgrund sah durch die Scheiben immer schwarz aus, die Mondscheibe erschien dunkelgrau".

In Santiago sind keinerlei besondere Phänomene beobachtet worden.

Santiago de Chile, Observatorio Astronómico, I 9 I 3 Jan. 29.

\title{
The Faint Equatorial Belts on the Planet Neptune
}

\author{
discovered with the 26 -inch Refractor of the U.S. Naval Observatory at Washington. By T. F. F. See.
}

[With a plate by way of illustration.]

As far back as 1902 , while occupied with the measurement of the planetary diameters and the determination of the constants of irradiation for the different planets and satellites of the Solar System, with the 26 -inch telescope of the Naval Observatory at Washington, I prepared a paper on the faint belts discovered on the planet Neptune in 1899. This has now remained unpublished for more than ten years, and as I recently found it among my manuscript papers, I deem it well to give it to the public without further delay, merely remarking that during the winter of $1899-1900$ the belts on Neptune were distinctly recognized by $\mathrm{Mr} . W . W$. Dinwiddie and Mr. G. H. Peters, both of whom saw the markings substantially as drawn by the writer, in the sketches now published.

In the drawing of the belts on Neptune here reproduced, the markings are perhaps a little too distinct, but this somewhat too great definiteness seems to be inherent in the nature of any sketch on a sensible scale, while on the very sinall disc of Neptune it is difficult to make out more than a general resemblance to the outlines here traced. But the separate sketches were made on different nights and I believe the series to give a faithful representation of the appearance of the planet.

At the end of the account of the Belts on Neptune I have added a notice of the discovery of the belts on the other major planets, which will I trust not prove to be wholly devoid of interest to students of this subject.

Soon after beginning observations of the Satellite of Neptune on October $6^{\text {th }}, 1899$, a period of good seeing commenced which lasted for about six weeks. The air was very steady, and on many nights, about three o'clock in the morning, a bank of fog beginning over the Potomac river would stretch over the city and at length envelop the Observatory. During this period the most difficult double stars were measured, and on many nights the disc of the planet Neptune came out with unusual sharpness. While occupied with the measure of the Satellite on October the $10^{\text {th }}$, a mottled appearance on the disc of the planet accidentally attracted attention.

The first drawing is taken from a sketch made on that night, and the others have been added since. As the observer had not contemplated studying the planet for surface markings, little further thought was given to the matter, till attention was again arrested by the unexpected appearance of beaded bands on the still and foggy night of Oct. $24^{\text {th }}$, when the disc of the planet came out with unexpected sharpness. The ball of Neptune seemed small, very sharply defined, perfectly motionless, and of a greenish or greyish color.

The stillness of the night may be judged by the fact that the great telescope clearly resolved the components of 95 Ceti, the most difficult of known double stars, which had never before been measured at Washington. 85 Pegasi, $\boldsymbol{x}$ Cygni and $x$ Pegasi are some of the other difficult stars measured on the best nights, when the belts on Neptune came out faintly against the brighter body of the planet.

In general the bands on Neptune were found to be extremely faint, but on a few occasions they came out with more distinctness. The plate gives the bands as noted at the time, and from these sketches it is easy to infer their general character. Assuming that they are parallel to the equator of the planet, it appears that the inclination of this plane to the plane of the Satellite's orbit does not surpass $20^{\circ}$. Professor S. F. Brown was led from theoretical considerations to conclude that this inclination is about $18^{\circ}$.

The uncertainty in the direction of faint belts seen on so small a disc is of course too great to enable us to fix the ascending node of Neptun's Equator on the plane of the Satellite's orbit. Whether future observations will furnish more definite information on this point remains to be seen. But $I$ think it proper to point out that these phenomena are probably the most difficult yet disclosed in the Solar System; and observers who recognize them even with good telescopes under the best possible conditions will have to be very keen sighted and patient in waiting for the best moments of the night and the best nights of the year.

Not a moment of the season of 1899-1900 which gave promise of results was allowed to pass unimproved, and it only seems proper for the writer to say that he passed many long nights in the study of Neptune, when once the existence of the bands became known. A fair perquisite of steadiness is ability to separate the companion of 95 Ceti, of which an orbit is given in A.N. 3629 . This star precedes Neptune by $2^{\mathrm{h}} 30^{\mathrm{m}}$ in right ascension, but in the present position the planet is sufficiently close by to serve as a test of steadiness.

On several occasions during his use of the 26 -inch telescope at Washington, Prof. Asaph Hall suspected mottlings on the surface of Neptune, but he could never make out the details with sufficient clearness to obtain results worth publishing. Subsequently Prof. S. F. Brown noticed an unsymmetrical appearance of the planet's disc.

The chief interest attaching to the discovery of equatorial belts on the planet Neptune arises from the circumstance that 